\title{
Alpha-fetoprotein as a differential marker between bladder cancer and Schistosomiasis among Egyptian patients
}

\author{
Maghraby A.S**, Samia A. Ahmed*, Ayman M. Metwally**, and Khalid, $\mathbf{H}^{\wedge}$. \\ *Therapeutic Chemistry Department National Research Center, Dokki, Cairo. \#Infectious \\ Diseases and Immunology group, Center of Excellence for Advanced Studies. ** Technology \\ of Medical Laboratory Department, College of Applied Medical Sciences, Misr University \\ For Science and Technology, 6th of October, Egypt, ${ }^{\boldsymbol{\Lambda}}$ National Cancer Institute, Cairo.
}

\begin{abstract}
Introduction: Schistosomiasis is considered as a widespread problem that affects Egyptians at different ages (WHO, 1993). It is well known that the high incidence of bladder carcinoma in schistosomal patients also represents a great risk to Egyptian society.

Objective: This study represents a survey on the changes which took place in AlphaFetoprotein (AFP) levels as a differential marker among Egyptian patients suffering from urinary bilharzial infection and bladder cancer.

Methodology: A partial study was carried out on four post-operative patients and followed up for sixty three days after chemotherapeutic treatment using immunoenzymatic mediated assay.

Results: It was found that bladder cancer leads to obvious significant increase in AFP levels, while schistosomal infection causes a non-significant decrease as compared to healthy control. Although the combination between schistosomal infection and cancer leads to a significant decrease in AFP level compared to non bilharzial cancer cases, there was no significant correlation with healthy cases.

Conclusion: It should be pointed out that the somewhat constant level of AFP in the sera of all patients was due to chemotherapeutic treatment. Also, it can be noticed that there is a significant positive correlation with progress of cancer grades.

Key words: Alpha-Fetoprotein, schistosomal infection, urinary bilharzial infection and bladder cancer.
\end{abstract}

Abbrevations: AFP: Alpha-Fetoprotein

\section{Introduction}

Where schistosomiasis remains endemic, a great deal has been published from Egypt about the role played by schistosoma parasite in development of malignant lesions in bladder (Ammal et al., 1992).

Carcinoma of the urinary bladder is the most common malignancy in the Middle-East and parts of Africa where schistosomiasis is a widespread problem. Much evidence supports the association between schistosomiasis and bladder cancer: this includes the geographical correlation between the two conditions, the distinctive pattern of gender and age at diagnosis, the clinical and pathological identity of schistosoma- associated bladder cancer, and extensive evidence in experimentally infected animals (Mostafa et al., 1999). So, the size of bilharzial problem and its complication needs more careful studies to demonstrate new marker to clarify the effect of bilharziasis in the development of carcinogenesis ( $\mathrm{Gu}$ et al., 1987). So, alpha-fetoprotein (AFP) is the marker of choice to study in this research. AFP is a serum glycoprotein, initially identified in human sera in 1956 as one of the two major proteins in fetal blood (Bergstrand and Czar, 1956). It is marked for hepato-cellular and germ cell carcinoma. Its synthesis by embryonal liver cells is virtually inhibited during adult life. Thus, it is not demonstrable in normal tissues but has been found in traces in adult human sera, this ratio began to increase with some body disorders and can be determined by some more sensitive 


\section{Maghraby A.S et al}

radioimmunoassay (Albert, 1979). In testicular cancer, lactate dehydrogenase (LDH), AFP, and human chorionic gonadotropin (hCG) are essential markers not only to determine the tumor stage but also for the prognosis of the patients (Shimazui et al., 2004). Asymptomatic individuals were screened on a voluntary basis using a panel of tumor markers, including AFP, CA 125, CA 15-3, CA 19-9, carcinoembryonic antigen (CEA), prostate specific antigen (PSA), chromogranin A ( $\mathrm{CgA})$, and squamous cell specific antigen (SCC) for cancer at Chang Gung Memorial Hospital in Taiwan (Tsao et al., 2006).

Complete ablation rates after a single session of radiofrequency ablation (RFA) of hepatocellular carcinoma (HCC) vary from $48 \%$ to $97 \%$. Limited data are available regarding risk factors and prognostic significance of incomplete ablation. By univariate analysis, it was found that absence of previous transarterial chemoembolization (TACE), preoperative serum alfa-fetoprotein was less or equal 100 $\mu \mathrm{g} / \mathrm{mL}$, and complete response after further treatment of incomplete ablation were associated with better overall survival in patients with incomplete ablation (Lam et al., 2008). Antigen A2/3 is alternative to alfa-fetoprotein (AFP) it was induced by heavy metal salts $(\mathrm{Pb} 2+$ and $\mathrm{Cd} 2+)$ in the liver of adult rats and AFP+/A2/3(-) clones of hepatomas; the attenuation of AFP synthesis occurred simultaneously (Poltoranina et al., 2007).

Several evidences support the association between the two diseases. So, our works represents a survey on the changes which took place in AlphaFetoprotein (AFP) levels as differential marker among Egyptian patients suffering from urinary bilharzial infection and bladder cancer.

\section{Subjects and Methods}

\section{Immunoenzymatic mediated assay (IEMA):}

The immunoenzymatic mediated assay is based on the principle of a "sandwich" formed of the analyte to be detected between two specific monoclonal antibodies directed against two different epitopes on the analyte molecule. Measurement of the activity is performed by adding a colorless chromogen solution. The action on chromogen produces a color which can be measured by ELISA reader (SORIN-BIO-MEDICA).

\section{Subjects:}

This work was conducted on 40 subjects including 36 patients submitted to the Surgical and Internal Medicine Departments in National Cancer Institute, Cairo University. The investigated patients were divided into five main groups according to the histological diagnostic reports supplied by the pathology department in the institute. The bilharzial infection was based on the stool and urine examinations documented in the disease history reports associated with patients submitted to Theodor Bilharz Institute.

The patients groups were:

1-Patients having bladder cancerous at three grades (12 patients at grades I, II and III)

2-Patients having bilharzial bladder cancer (12 patients at grades I, II and I

3-Patients were suffering from urinary schistosomiasis (4 patients).

4-Patients having bladder cancer and submitted to chemotherapy treatment (4 patients).

5-Patients suffering from bladder cancer post-operative (4 patients).

Four healthy persons were included in this study as a control group.

\section{Specimen collection:}

Venous blood samples were collected from all the previous groups and sera were separated and kept at $-70^{\circ} \mathrm{C}$ until the assay.

\section{Statistical analysis:}

Statistical analysis was done using ANOVA test and regression line analysis.

\section{Results}

One of the most clinically useful tumor associated antigens of this class is AFP which has been widely studied in patients with gastrointestinal cancer, therefore we try to demonstrate the changes which might took place in AFP levels as a tumor marker among Egyptian patients 
suffering from both bilharzial infestation and cancer bladder.

Table (2) show the effect of schistosomal infection which leads to slight decrease in AFP levels, with percent change equal $12.5 \%$ referred to control. The difference was statistically insignificant $(\mathrm{P}$ $<0.05)$ by ANOVA.

Data summarized in tables (2-4) demonstrated the AFP levels in bilharzial and non-bilharzial bladder cancer compared to their levels in healthy cases. It is clear that cancerous infiltration resulted with highly significant increase which was higher in grade III than grade II and I in the two types of cancer. Although the combination between schistosomal infection and cancer lead to significant decrease in AFP level compared to non-bladder cancer cases, there was no significant difference with healthy cases. On the other hand, the non bilharzial cancer leads to significant elevation of AFP as compared to control cases. It is worthy mentioned that this decrease was significantly marked with the conversion to malignancy (Figs. 1, 2).

The specific treatment protocol for refractory carcinoma in situ of the bladder remains elusive. It is ultimately the combined decision of the clinician and patient to determine which course of management is most beneficial (Kim and Steinberg, 2001). In the present study, we used AFP to differentiate between postoperative and after therapy; whereas the addition of chemotherapy to surgery improved both disease-free and overall survival rates (El-Mawla et al., 2001). The statistical analysis showed that there has been no significant difference afteroperative or chemotherapy whereas $\mathrm{P}<0.05$ by using ANOVA test (Table 5). On the other hand, there was a significant difference post-operative and postchemotherapy as compared to control.

Table (1)

$\alpha$-Fetoprotein concentrations in serum of normal subj ects and patients with cancer bladder, bilharzial cancer bladder and Bilharzzziasis ( $\mathrm{n} g / \mathrm{ml}$ ).

\begin{tabular}{|c|c|c|}
\hline Groups & $\begin{array}{c}\alpha \text {-fetoprotein } \\
\text { ng /mI }\end{array}$ & Mean \pm S.D \\
\hline Bladder cancer Grade I & $5.0-4.8-4.9-4.9$ & $4.9 \pm 0.07$ \\
\hline Bladder cancer Grade II & $5.4-4.9-5.1-5.0$ & S.1 \pm 0.18 \\
\hline Bladder cancer Grade III & $5.6-6.3-6.0-5.1$ & S.75 0.4 \\
\hline $\begin{array}{c}\text { Bbilhazial bladder cancer } \\
\text { Grade I }\end{array}$ & $4.2-3.8-3.8-4.5$ & $4 \pm 0.2$ \\
\hline $\begin{array}{c}\text { Bbilhazial bladder cancer } \\
\text { Grade II }\end{array}$ & $4.7-4.0-3.9-4.5$ & $4.28 \pm 0.3$ \\
\hline $\begin{array}{c}\text { Bbilhazial bladder cancer } \\
\text { Grade III }\end{array}$ & $4.9-4.6-3.9-4.5$ & $4.48 \pm 0.36$ \\
\hline & & $3.5 \pm 0.2$ \\
\hline Biharzial cases & $3.5-3.6-3.2-3.8$ & $1.6 \pm 0.14$ \\
\hline Post - Oprative & $1.6-1.4-1.8-1.6$ & $1.7 \pm 0.2$ \\
\hline Post - Chemotherapy & $1.5-1.5-2.0-1.8$ & $3.95 \pm 0.26$ \\
\hline Normal cases & $3.8-4.3-4.1-3.6$ & \\
\hline
\end{tabular}


Table 2 : $\alpha$-Fetooprotein concentrations $(\mathrm{ng} / \mathrm{mL})$ in serum of urinary Schistosomasis, bladder cancer and bilharizial cancer patient as compared to control casses

\begin{tabular}{|c|c|c|c|}
\hline Groups & Mean \pm 0.26 & $\%$ change & $\mathbf{P}<$ \\
\hline Control & $4.0 \pm 0.26$ & - & - \\
\hline UrinarySchistosomasis & $3.5 \pm 0.2$ & 12.5 & 0.05 \\
\hline \multirow[t]{3}{*}{ Bladder cancer } & $4.9 \pm 0.01$ & 22.5 & 0.001 \\
\hline & $5.1 \pm 0.18$ & 27.8 & 0.001 \\
\hline & $5.8 \pm 0.8$ & 45.0 & 0.001 \\
\hline \multirow{3}{*}{$\begin{array}{l}\text { Bilharzial } \\
\text { Bladder } \\
\text { Cancer }\end{array}$} & $4.1 \pm 0.2$ & 2.5 & 0.001 \\
\hline & $4.3 \pm 0.3$ & 7.5 & 0.001 \\
\hline & $4.5 \pm 0.36$ & 12.5 & 0.001 \\
\hline
\end{tabular}

Table $3 \alpha$-Fetoprotein concentrations $(\mathrm{ng} / \mathrm{mL})$ in serum of bilharzial and non bilharzial bladder cancer patients as compared with Schistosomasis cases.

\begin{tabular}{|lr|c|c|c|}
\hline \multicolumn{2}{|c|}{ Groups } & Mean $\pm \mathbf{0 . 2 6}$ & $\%$ change & $P<$ \\
\hline \multicolumn{2}{|c|}{ UrinarySchistosomasis } & $3.5 \pm 0.2$ & - & - \\
\hline Bladder cancer & I & $4.9 \pm 0.07$ & 40 & 0.001 \\
\cline { 3 - 5 } & II & $5.1 \pm 0.18$ & 45.7 & 0.001 \\
\cline { 3 - 5 } & III & $5.8 \pm 0.4$ & 65.7 & 0.001 \\
\hline Bilharzial & I & $4.1 \pm 0.2$ & 17.14 & 0.01 \\
\cline { 2 - 5 } $\begin{array}{l}\text { Bladder } \\
\text { Cancer }\end{array}$ & II & $4.3 \pm 0.3$ & 22.9 & 0.01 \\
\cline { 3 - 5 } & III & $4.5 \pm 0.36$ & 28.6 & 0.001 \\
\hline
\end{tabular}

Table 4 The effect of bilharzial infection on serume (AfP) concentrations (ng/mL) on Bladder cancer patients.

\begin{tabular}{|c|c|c|c|}
\hline Groups & Mean \pm 0.26 & $\%$ change & $\mathbf{P}<$ \\
\hline Bladder cancer & $4.25 \pm 0.19$ & - & - \\
\hline Bilh-bladder cancer & $5.23 \pm 0.03$ & 23.1 & 0.001 \\
\hline \multirow{3}{*}{$\begin{array}{l}\text { Bilharzial } \\
\text { Bladder } \\
\text { Cancer }\end{array}$} & $4.1 \pm 0.2$ & 17.14 & 0.01 \\
\hline & $4.3 \pm 0.3$ & 22.9 & 0.01 \\
\hline & $4.5 \pm 0.36$ & 28.6 & 0.001 \\
\hline
\end{tabular}

Table 5 - The effect of Chemotheraputic treatment on serum (AFP) concentrations ( $\mathrm{ng} / \mathrm{mL}$ ) in Patient post operative.

\begin{tabular}{|l|c|c|c|}
\hline Groups & Mean \pm 0.26 & $\%$ change & $P<$ \\
\hline Post-operative & $1.6 \pm 0.14$ & 60 & 0.001 \\
\hline Post-Chemotherapy & $1.7 \pm 0.2$ & 57.5 & 0.001 \\
\hline Control & $4 \pm 0.26$ & - & - \\
\hline
\end{tabular}


Figure 1: Levels of alpha fetoprotein according to health status:
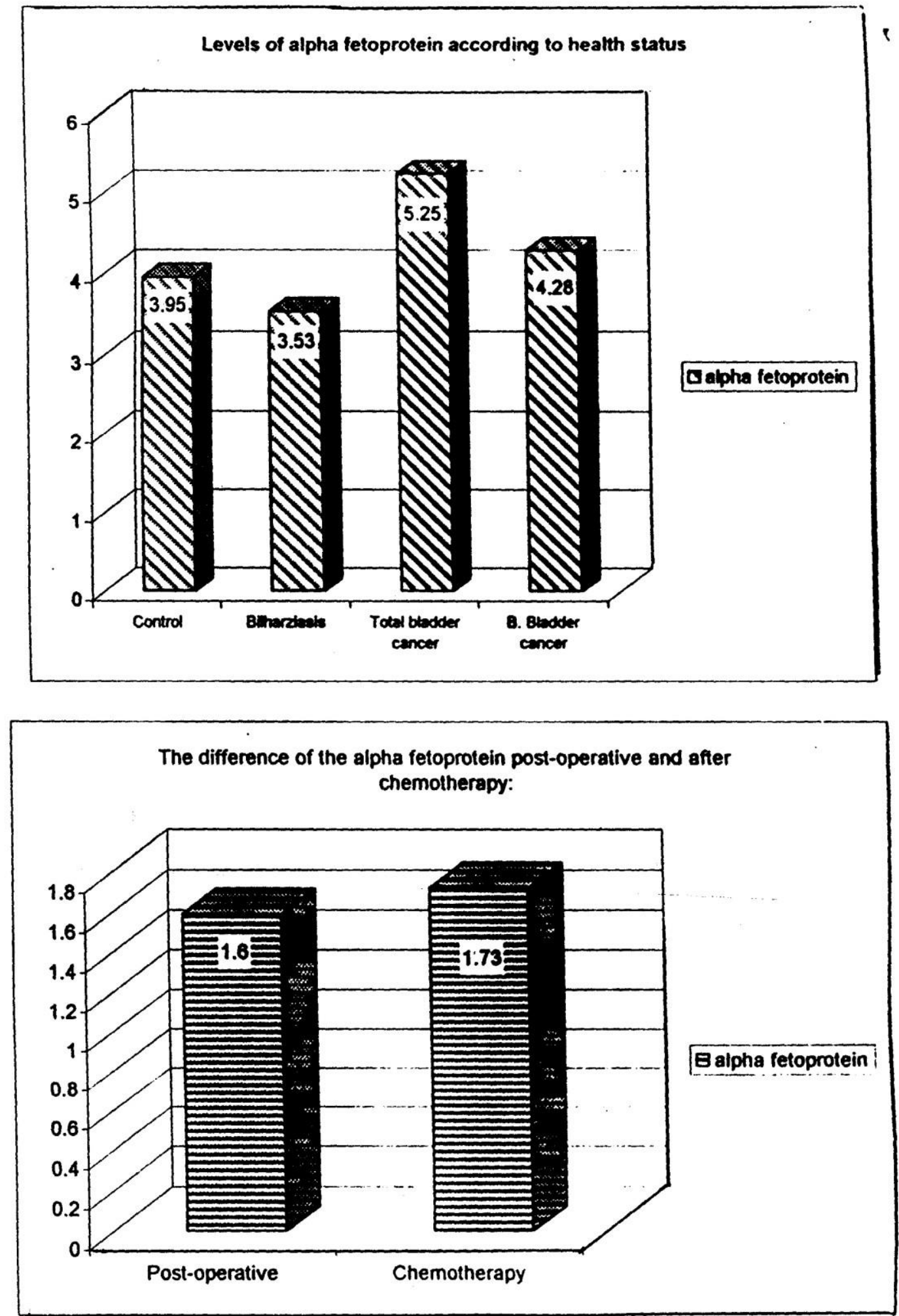

Figure 2: The difference of the alpha fetoprotein post-operative and after chemotherapy. 


\section{Maghraby A.S et al}

\section{Discussion}

The search for specific tumors markers is of considerable importance as new and more effective therapies for many neoplasms are becoming available. The ideal markers should be specific for the organ involved by the tumor and elevated in the majority of patients with neoplastic disease not in benign one (Berlin, 1981). A variety of substances circulating in serum are potentially useful as tumor markers such as certain glycoproteins. Some biochemical markers give a more precise and earlier diagnosis than the usual ones (Goffinet et al., 2001).

Our results were as similar to those obtained by Alsbti (1978) where as two hundred and eighty-four patients of various ages from an endemic area, diagnosed as having bilharziasis by the presence of living Schistosoma haematobium's ova in the midstream urine sample, have been investigated for the presence of AFP in the serum using radioimmunoassay. One hundred and fortyone $(49.6 \%)$, were positive. Wespic and Kirkatrick (1979) suggested that AFP elevated in $5-10 \%$ of patients with large liver metastases virtually exclusively from gastric and pancreatic patients. Also when we evaluated the effect of progressive grading of carcinoma on AFP levels, our data showed that AFP level increase progressively as cancer grades progresses reached the maximum values or grade III. So, there is a gradual significant positive correlation with progress of cancer grades. These results were in line with that detected by Joan et al. (1988) who found gradually increase in AFP in normal pregnant women and in complication with cancer in all grades. The same results were obtained in comparing the grades among the non bilharzial cancer. This can be attributed to the fact that in case of early grade the cells have more benign course rather than late grades, and this is also supported by Trojan et al. (1983) who studied the localization of AFP in different tissues including normal tissues in rat, baboon and mouse teratocarcinoma and they suggested that the incorporation of AFP was associated with the degree of differentiation. AFP and prostate-specific antigen (PSA) in serum are widely used as tumor markers in the evaluation of prognosis and management of patients with hepato-cellular carcinoma and prostate cancer, respectively. Reverse transcriptase polymerase chain reaction (RT-PCR) for AFP and PSA were used to identify circulating cancer cells in the blood of cancer patients. Broad expression of AFP was in several tissues and a large amount of AFP mRNA was found in fetal liver. PSA was expressed in prostate, salivary gland, pancreas and uterus. By RT-PCR, AFP and PSA mRNA were detected in several tumors, including salivary pleomorphic adenoma, hilar bile duct carcinoma, pancreatic carcinoma, transitional cell carcinoma of urinary bladder and thyroid papillary carcinoma. Furthermore, AFP and PSA mRNAs were frequently detected by RT-PCR, even in peripheral blood cells from healthy volunteers (Ishikawa et al., 1998). The early diagnosis of bladder cancer allows for effective local treatment and optimizes the success of surgical therapy. Basic fetoprotein (BFP) has no correlation with tumor grade, while cytology had a strong association. Linear regression analysis showed the significant correlation between BFP level and tumor size. The detection rate of bladder cancer was higher by the combination of BFP and cytology than by using one alone (Ichikawa et al., 2000).

\section{Conclusion}

In conclusion, we can use AFP level as a differential marker among Egyptian patients suffering from urinary bilharzial infection and bladder cancer infestation using immunoenzymatic mediated assay.

\section{References}

1. Albert E (1979): In compendium of assays for immunodiagnosis of human cancer, Elsevier, North- Holland, New York, , Page 35.

2. Alsabti EA (1978): Serum alpha fetoprotein (AFP) in bilharziasis. Br J Urol., 50(2):1345. 
3. Akaza H and Shimazu, T ( 2004): Significance of current bio-and molecularmarkers in urological cancers. Nippon Hinyokika Gakkai Zasshi., 31(7):1008-14.

4. Ammal M M, Aly M A, Awatif N N, Abdel-Mageed A, Kamal H M, Faayed ME and Morsy TA (1992): Eosinophilic infiltration in Egyptian patients with schistosomal or non schistosomal urinary bladder lesions., J. Trop. Med., 1(5), 51-55.

5. Bergstrand CG and Graz B (1956): Demonstration of a new protein fraction in serum from the human fetus., J. Clin. Lab. Invert., 8: 174.

6. Berlin N L (1981): Tumor markers in cancer prevention and detection., Cancer, 47, 1151.

7. El-Mawla $\mathbf{N}$ G, El- Bolkainy $M \mathbf{N}$ and Khaled $H$ M (2001): Bladder cancer in Africa: Gan To Kagaku Ryoho. Update. Semin Oncol., 28(2), 178-8.

8. Tsao K C,Wu T L, Chang P Y and Hong J H (2006): Detection of carcinomas in an asymptomatic Chinese population: advantage of screening with multiple tumor marker., J. lin. Lab. Anal., 20(2):42-6.

9. Goffinet F, Maillard F, Fulla Y and abrol D( 2001): Biochemical markers (without markers of infection) of the risk preterm delivery. Implications for clinical practice. Eur. J. Obstet. Gynecol. Reprod. Biol., 94 (1): 59-68.

10. Gu J R, Hu LF, Wan D F and Hong J X. (1987): Cancer of liver, oesophagus, bladder and Springer verlog, Neww York, $10^{\text {th }} \mathrm{Ed}$,

11. Ishikawa T, Kashiwagi H, Iwakami Y, Hirai M, Kawamura TAiyoshi Y, Yashiro T, Ami Y, Uchida K, Miwa M ( 1998): Expression of alpha fetoprotein and prostate specific antigen genes in several tissues and detection of mRNAs in normal circulating blood by reverse transcriptase polymerase chain reaction., Jpn Clin Oncol., 28(12):723-8.

12. Ichikawa T, Nakayama Y, Yamada D, Saegusa M, Asano S, Aramaki, K.
(2000): Clinical evaluation of basic fetoprotein in bladder cancer., Nippon Hinyokika Gakkai Zasshi. 91: 579-83

13. Joan F.Z. Peter RP and Philip DM ( 1988): Clinical chemistry in diagnosis and treatment. Chapter (7) page, 144.

14. Kim J C, Steinberg G D (2001): Medical management of patients with refractory carcinoma in situ of the bladder. Drugs Aging.;18(5):335-44

15. Lam VW, Ng KK, Chok KS, Cheung TT, Yuen J, Tung H, Tso WK, Fan ST, Poon RT. ( 2008): Incomplete ablation after radiofrequency ablation of hepatocellular carcinoma: analysis of risk factors and prognostic factors. Ann Surg Oncol. 15(3):782-90.

16. Mostafa $M H$ and Sheweita SA, O'Connor PJ. (1999): Relationship between schistosomiasis and bladder cancer., Clin Microbiol Rev. 12(1):97-111.

17. Poltoranina VS, Kuprina NI, Eraĭzer TL, Karamova ER, Abelev GI.( 2007): The purification of the protein alternative to alfa-fetoprotein. Vestn Ross Akad Med Nauk., (11):41-5.

18. Shimazui T and Akaza H.9 (2004): Significance of current bio- and molecularmarkers in urological cancers Gan To Kagaku Ryoho., 31(7):1008-14.

19. Trojan J, Gaillard JA, Uriel J. (1983): Localization of alpha fetoprotein in neuroepithelial derivatives of murine teratocarcinomas., Ann Pathol., 3(2):137-45

20. Tsao K C, Wu T L, Chang PY, Hong J H, Wu JT, Ichikawa T, Nakayama Y, Yamada D, Saegusa $M$, and Asano $S$ (2000): Clinical evaluate of basic fetoprotein in bladder cancer, 91(7-8):57983.

21. Wepsic HT, Kirkpatrick. (1979): Alphafetoprotein and its relevance to human disease Gastroenterology., 77 (1):787-96.

22. World Health Organization.(1993): The control of schistosomiasis. Second report of the WHO Expert Committee. World Health Organ Tech Rep Ser.;830:81-86. 


\section{تقييم لمستويات البروتين الجنينى ـالفا كعامل مميز للتفرقة بين سرطانى المثانة و المثانة البلهارسي في المرضي المصريين}

أمانى سبد مغربى \#* - سامية عبد العزيز أحمد * أيمن محمد متولي ** - حسين مصطفى خالا

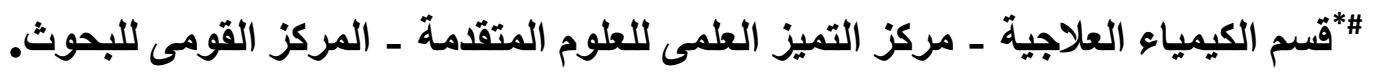

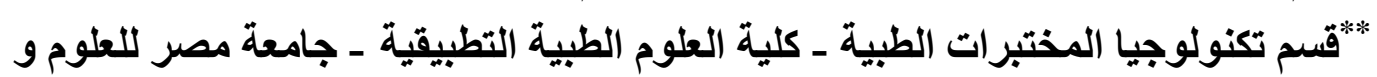
التكنولوجيا ـ 4 قسم طب الأورام - المعهد القومى للأورام.

يعد البروتين الجنينى ـ ألفا من دلالات الأورام ذات الطبيعة البروتينية و التى تتكون أساسا فى في

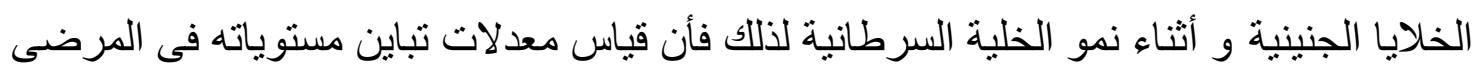
المصابين بسرطانى المثانة و المثانة البلهارسى ذو أهمية للتفرفة بينهم ـ لذلك يهدف البحث إلى

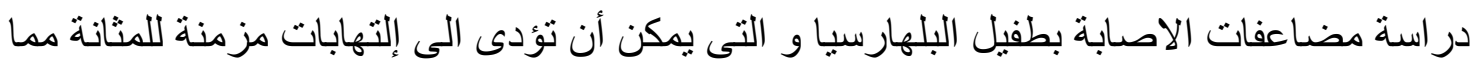
ينتج عنه إفراز لبعض البروتينات و التى تظهر فى الحالات السرطانية (سرطان المثانة موضع الدراسة) مثل البروتين الجنيني - ألفا. إضافة إلى مقارنة نسبته فى مرضى سرطان المثانة فقط لمعرفة تأثير عدوى البلهارسيا و تطور ها إلى مضاعفات سرطان المثانة على إنتاج هذا البروتين الجنينى • إستتنج الدر اسة أن الأصابة بسرطان المثانة يؤدى الى إرتفاع ملحوظ فى مستويات البروتين الجنينى ـألفا فى حين كانت للاصسابة بعدوى البلهارسيا تثبيط غير معنوى لمستو اه مقارنة بالمجمو عة الضابطة الأصحاء .كما أوضحت الدر اسة أن تطور عدوى البلهارسيا إلى مضاعفاتها من سرطان المثانة يؤدى إلى نقص معنوى واضح فى مستوايات البروتين الجنينى ـألفا مقارنة

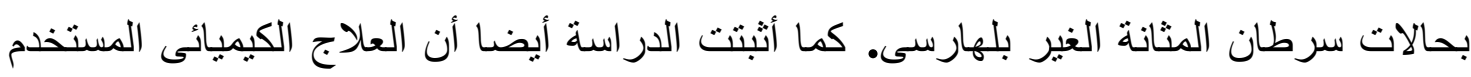
يؤدى إلى ثبات مستويات البروتين الجنينى ـ ألفا إلى حد ما. كما يلاحظ أن هناك علافة إيجابية

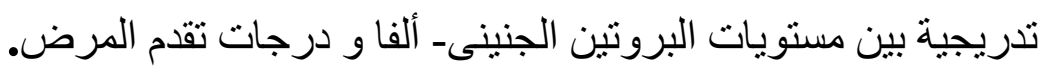

